\title{
BOSNIAN LINGUISTIC USAGES IN THE LITERARY LANGUAGE OF SKENDER KULENOVIĆ
}

\section{PhD Ahmet Kasumović}

Book review

\section{Author: Marijana Nikolić}

After quite a long period of time, there appeared another scientifically researched book on yet another famous and significant Bosnian-Herzegovinian author. A young Doctor of Philosophy in the fields of philology and linguistics, Marijana Nikolić, published a book titled Bosnian Linguistics Usages in the Literary Language of Skender Kulenović. In her book, the author explains the following traits: Phonology, Phonostylistics, Morphology, Morphostylistics, Word formation, Nomina as a word-formative category, constituent derivatives with transposed meanings, as well as neologisms in the creative works of Bosnian-Herzegovinian author Skender Kulenović. The book also contains a list of Abbreviations, Works cited and Bibliography, Name- and Subject index, and also numerous Tables. The book of 165 pages in total was published by Off-set, in August of 2015 in Tuzla, Bosnia-Herzegovina.

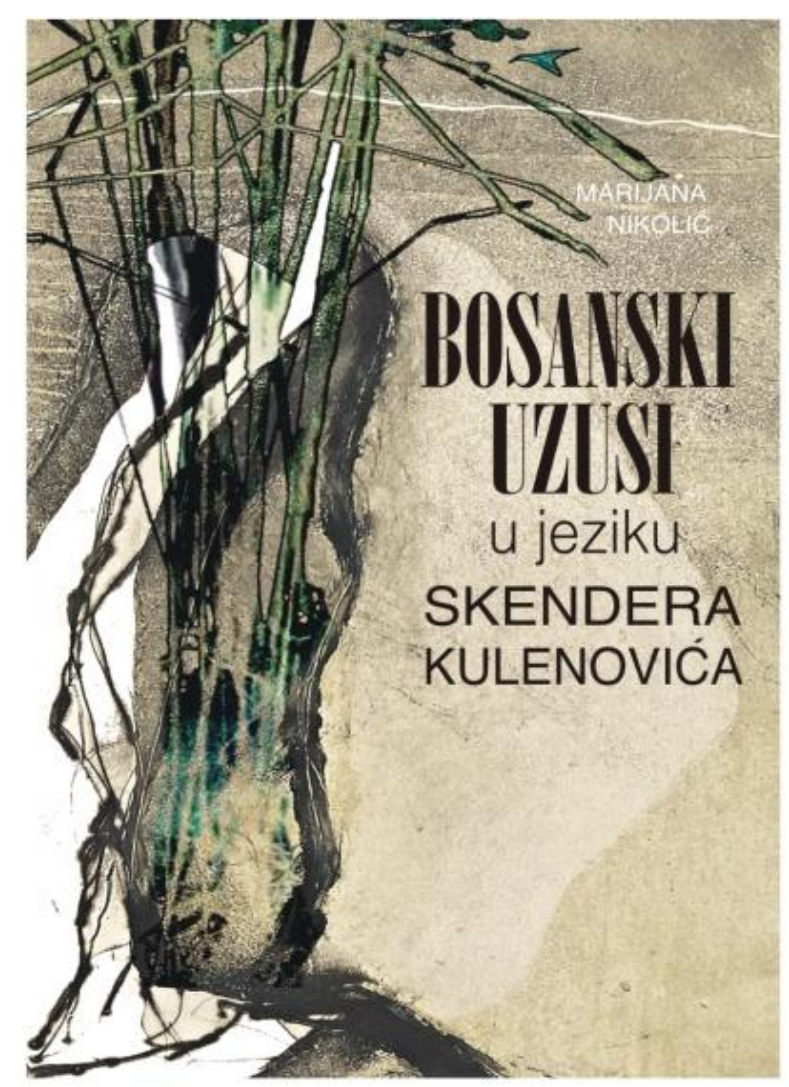

